\title{
Kajian Pemilihan SMA Swasta Terfavorit Sebagai Acuan Bagi Calon Siswa yang akan Melanjutkan Sekolah ke SMA Swasta di Kota Pangkalpinang
}

\author{
Parlia Romadiana \\ Program Studi Magister Ilmu Komputer, Program Pascasarjana, Universitas Budi Luhur \\ Jl. Ciledug Raya, Petukangan Utara, Kebayoran Lama, Jakarta Selatan 12260 \\ Telp. (021) 595753, Fax. (021) 5869225 \\ rparlia.pr@gmail.com
}

\begin{abstract}
Abstrak - SMA Swasta merupakan sekolah menengah atas yang didirikan oleh yayasan dan bukan milik pemerintah namun tetap di kontrol oleh dinas pendidikan. Pada saat ini, di kota Pangkalpinang terdapat banyak SMA Swasta yang saling bersaing baik dalam bidang fasilitas, tenaga pengajar, prestasi maupun kegiatan ekstrakulikuler. Hal itu membuat para siswa menjadi bingung dalam menentukan sekolah mana yang baik untuk mereka. Kajian pemilihan SMA Swasta ini dibuat agar dapat dijadikan acuan bagi calon siswa untuk memilih SMA Swasta Terfavorit di Pangkalpinang dengan menggunakan metode Analitycal Hierarchy Process(AHP). AHP merupakan metode untuk memecakan suatu situasi yang tidak terstruktur ke dalam beberapa komponen dalam bentuk hierarki, member penilaian subjective yang diberikan oleh responden ahli dengan tingkat konsistensi tidak kurang atau sama dengan 10\% menggunakan software Expert Choice. Setelah dilakukan analisis dan perhitungan hasil quisioner, dapat disimpulkan bahwa SMA Swasta Terfavorit di Kota Pangkalpinang yaitu SMA Santo Yosef dengan bobot sebesar 46,9\%, dilanjutkan dengan SMA THB dengan bobot sebesar $29,6 \%$, dan alternatif yang terkecil yaitu SMA Swadaya dengan bobot sebesar $23,5 \%$.
\end{abstract}

Kata Kunci: SMA Swasta Terfavorit, Analitycal Hierarchy Process, Sistem Pendukung Keputusan, Expert Choice.

\section{Pendahuluan}

Dunia pendidikan di Indonesia saat ini sangat berkembang. Perkembangan tersebut membuat setiap sekolah termasuk sekolah swasta terus bersaing dalam memberikan pelayanan yang terbaik bagi siswa untuk mendapatkan predikat terbaik. Persaingan tersebut juga terjadi di SMA Swasta di Kota Pangkalpinang. Seluruh SMA Swasta di Kota Pangkalpinang terus berlomba-lomba untuk menarik perhatian para siswa yang ingin melanjutkan sekolah ke SMA Swasta dengan memberikan kualitas yang terbaik dalam bidang fasilitas yang dimiliki, tenaga pengajar, prestasi serta kegiatan yang dilaksanakan di sekolah tersebut. Hal itu membuat para calon siswa mampunyai banyak pilihan dan tidak adanya sistem atau kajian yang dapat dijadikan acuan dalam memilih SMA swasta mana yang terbaik untuk menjadi tempat melanjutkan sekolah. Berdasarkan permasalahan tersebut, peneliti ingin mengkaji SMA Swasta Terfavorit di Kota Pangkalpinang dengan menggunakan metode Analitycal Hierarchy Process(AHP). Hasil dari penelitian ini diharapkan dapat dijadikan acuan bagi para calon siswa yang akan melanjutkan sekolah ke jenjang sekolah menengah atas untuk menentukan SMA Swasta terfavorit.

\section{LANDASAN TEORI}

\section{A. Sistem Pendukung Keputusan}

Sistem merupakan kumpulan elemen yang saling berkaitan yang bertanggung jawab memproses masukan (input) sehingga menghasilkan keluaran (output) [4]. Sistem pendukung keputusan adalah sistem berbasis komputer interaktif yang membantu pengguna dalam penilaian dan pemilihan. Sistem tidak hanya menyediakan penyimpanan dan pengambilan data tapi juga meningkatkan akses informasi tradisional dengan dukungan untuk pembuatan model pengambilan keputusan dan penalaran berbasis model [6].

\section{B. Analytical Hierarchy Process}

Analytical Hierarchy Process (AHP) dikembangkan oleh Dr. Thomas L. Saaty dari Wharton School of Business pada tahun 1970-an untuk mengorganisasikan informasi dan judgement dalam memilih alternatif yang paling disukai [5]. Dengan menggunakan AHP, suatu persoalan yang akan dipecahkan dalam suatu kerangka berpikir yang terorganisir, sehingga memungkinkan dapat diekspresikan untuk mengambil keputusan yang efektif atas persoalan tersebut. Persoalan yang kompleks dapat disederhanakan dan dipercepat proses pengambilan keputusannya. Adapun prinsip kerja AHP adalah sebagai berikut: 
1) Penyusunan Hierarki

Persoalan yang akan diselesaikan diuraikan menjadi unsur-unsurnya, yaitu kriteria dan alternatif, kemudian disusun menjadi struktur hirarki.

2) Penilaian Kriteria dan Alternatif.

Kriteria dan alternatif dinilai melalui perbandingan berpasangan. Nilai dan definisi pendapat kualitatif dari skala perbandingan Saaty dapat dilihat pada tabel berikut:

Tabel 1. Skala Perbandingan Saaty

\begin{tabular}{|l|l|}
\hline Nilai & \multicolumn{1}{|c|}{ Keterangan } \\
\hline 1 & $\begin{array}{l}\text { Kriteria/Alternat A sama } \\
\text { penting dengan } \\
\text { kriteria/alternatif B }\end{array}$ \\
\hline 3 & A sedikit lebih penting dari B \\
\hline 5 & A jelas lebih penting dari B \\
\hline 7 & $\begin{array}{l}\text { A sangat jelas lebih penting } \\
\text { dari B }\end{array}$ \\
\hline 9 & A mutlak lebih penting dari B \\
\hline $2,4,6$, & $\begin{array}{l}\text { Apabila ragu-ragu antara dua } \\
\text { nilai yang berdekatan }\end{array}$ \\
\hline
\end{tabular}

Nilai perbandingan A dengan B adalah 1(satu) dibagi dengan nilai perbandingan $\mathrm{B}$ dengan $\mathrm{A}$.

3) Penentuan Prioritas

Untuk setiap kriteria dan alternatif, perlu dilakukan perbandingan berpasangan (pairwise comparisons). Nilai-nilai perbandingan relatif kemudian diolah untuk menentukan peringkat relatif dari seluruh alternatif.

4) Konsistensi Logis

Semua elemen dikelompokkan secara logis dan diperingkatkan secara konsisten sesuai dengan suatu kriteria yang logis. Perhitungan indeks konsistensi (CI), pengukuran ini dimaksudkan untuk mengetahui konsistensi jawaban yang akan berpengaruh pada kesahihan hasil. Rumusnya adalah sebagai berikut:

Semua elemen dikelompokkan secara logis dan diperingkatkan secara konsisten sesuai dengan suatu kriteria yang logis. Untuk mengetahui apakah CI dengan besaran tertentu cukup baik atau tidak, perlu diketahui rasio yang dianggap baik, yaitu apabila:

Rumus CR (Consistency Ratio) adalah:

$$
\mathrm{CR} \leq 0,1
$$

Semua elemen dikelompokkan secara logis dan diperingkatkan secara konsisten sesuai dengan suatu kriteria yang logis.

CR merupakan parameter yang digunakan untuk memeriksa apakah perbandingan berpasangan telah dilakukan dengan konsekuen atau tidak. Nilai RI merupakan nilai random indeks yang dikeluarkan oleh Oarkridge Laboratory seperti yang ditampilkan pada tabel 3 berikut:
Tabel 2. Skala Nilai Random Indeks Oarkridge Laboratory

\begin{tabular}{|c|c|}
\hline $\mathrm{N}$ & $\mathrm{RI}$ \\
\hline 1 & 0.00 \\
\hline 2 & 0.00 \\
\hline 3 & 0.58 \\
\hline 4 & 0.90 \\
\hline 5 & 1.12 \\
\hline 6 & 1.24 \\
\hline 7 & 1.32 \\
\hline 8 & 1.41 \\
\hline 9 & 1.45 \\
\hline 10 & 1.49 \\
\hline 11 & 1.51 \\
\hline 12 & 1.48 \\
\hline 13 & 1.56 \\
\hline
\end{tabular}

\section{Tinjauan Studi}

Berikut ini merupakan tinjauan studi yang relevan dengan penelitian ini yaitu :

Tabel 3. Tinjauan Studi Penelitian relevan

\begin{tabular}{|c|c|}
\hline Judul Penelitian & Hasil Penelitian \\
\hline $\begin{array}{l}\text { Sistem Penunjang Keputusan } \\
\text { Pemilihan Sekolah Menengah } \\
\text { Kejuruan Teknik Komputer } \\
\text { Dan Jaringan Yang Terfavorit } \\
\text { Dengan Menggunakan Multi- } \\
\text { Criteria Decision Making [1] }\end{array}$ & $\begin{array}{l}\text { nilai bobot } 44,8 \% \text { dari } \\
\text { jawaban reponden } \\
\text { memilih SMK TI 2, } \\
\text { nilai bobot } 29,3 \% \text { dari } \\
\text { jawaban reponden } \\
\text { memilih SMK TI } 1 \text { dan } \\
\text { nilai bobot } 25,9 \% \text { dari } \\
\text { jawaban reponden } \\
\text { memilih SMK TI 3 } \\
\text { sebagai pilihan sekolah } \\
\text { mereka }\end{array}$ \\
\hline $\begin{array}{l}\text { Sistem penunjang } \begin{array}{l}\text { keputusan } \\
\text { perangkat }\end{array} \\
\text { pemilihan } \\
\text { pemrosesan data menggunakan } \\
\text { metode Analytical Hierarchy } \\
\text { Process (AHP) dan Multi- } \\
\text { Criteria decision Making } \\
\text { (MCDM) [2] }\end{array}$ & $\begin{array}{lr}\text { Desktop } & \text { merupakan } \\
\text { prioritas utama dari } \\
\text { alternatif strategis yang } \\
\text { diambil r } \\
\text { penerapan pemilihan } \\
\text { perangkat pemrosesan } \\
\text { data yang dibuktikan } \\
\text { melalui pengolahan } \\
\text { data responden ahli } \\
\text { disusul urutan prioritas } \\
\text { berikutnya Notebook } \\
\text { dan Tablet }\end{array}$ \\
\hline $\begin{array}{l}\text { Sistem penunjang keputusan } \\
\text { pemilihan perangkat lunak } \\
\text { pengolah citra dengan metode } \\
\text { Multi-Criteria } \\
\text { Making Decision } \\
\text { Analytical Hierarchy Process } \\
\text { (AHP) [3] }\end{array}$ & $\begin{array}{l}\text { Dreamweaver sebagai } \\
\text { prioritas utama disusul } \\
\text { Frontpage sebagai } \\
\text { prioritas kedua dan } \\
\text { Photoshop sebagai } \\
\text { prioritas ketiga }\end{array}$ \\
\hline
\end{tabular}




\section{MeTODE PENELITIAN}

Penelitian ini menggunakan metode Analytical Hierarchy Process dengan kerangka konsep sebagai berikut:

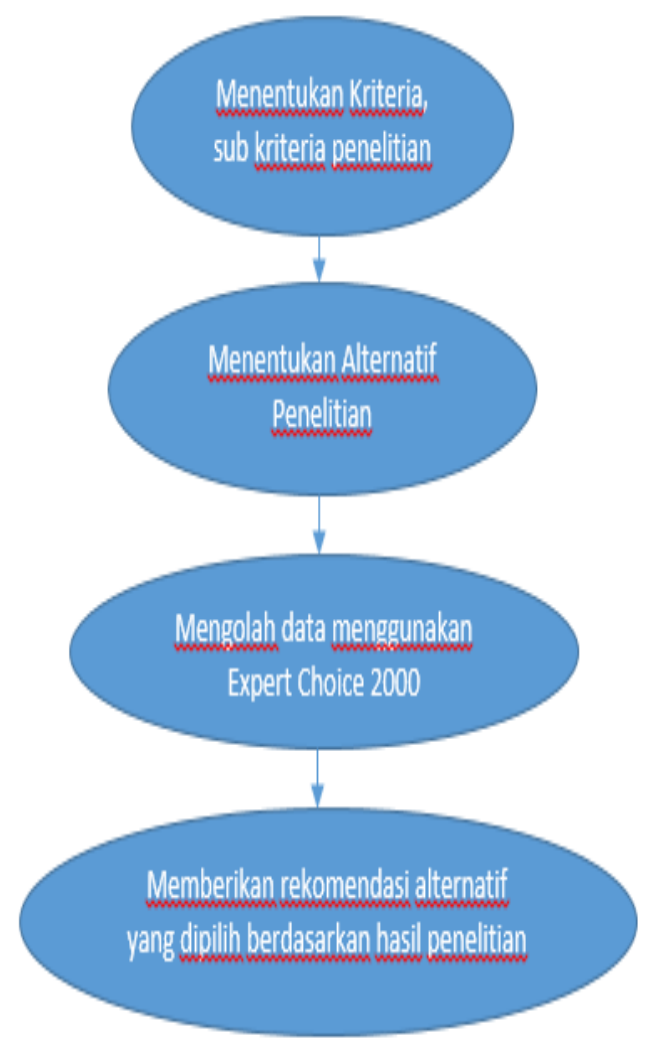

Gambar 1. Kerangka konsep penelitian

Adapun kerangka konsep tersebut dijabarkan dalam langkah-langkah penelitian sebagai berikut:

\section{A. Analisis Masalah}

Analisa Masalah dilakukan dengan melakukan pengamatan kepada calon siswa yang akan melanjutkan sekolah ke jenjang SMA swasta. Hasil dari pengamatan tersebut digunakan untuk menentukan kriteria dan sub kriteria penelitian. Selanjutnya menentukan alternative berdasarkan kebutuhan kriteria dan sub kriteria yang telah ditentukan. Alernatif dalam penelitian ini sebanyak 3 SMA Swasta yang berada di Pangkalpinang yang memenuhi kriteria dan sub kriteria dalam pemilihan SMA swasta Terfavorit. Data yang telah diperoleh kemudian dibuat dalam kuisioner untuk diisi oleh pakar. Dalam penelitian ini pakar yang digunakan yaitu staf Dinas Pendidikan kota Pangkalpinang sebanyak 4 orang. Pakar tersebut dipilih karena staf dari Dinas Pendidikan kota pangkalpinang mengetahui informasi mengenai dunia pendidikan di kota Pangkalpinang. Hasil dari kuisioner tersebut diolah dengan metode Analytical Hierarchy Process (AHP) dengan bantuan tools Expert Choice 2000.
Jurnal SISFOKOM, Volume 05, Nomor 01, Maret 2016

\section{B. Pemecahan Masalah dengan Analytical Hierarchy} Process (AHP)

Langkah-langkah sistem pendukung keputusan dalam penelitian ini ditentukan dengan menentukan kriteria, sub kriteria, dan alternative yang dijelaskan dalam tabel berikut ini:

Tabel 4. Kriteria, Sub Kriteria, dan Alternatif Pemilihan SMA Swasta Terfavorit

\begin{tabular}{|c|c|c|}
\hline Kriteria & Sub Kriteria & Alternatif \\
\hline Fasilitas & $\begin{array}{ll}\text { 1. } & \text { Perpustakaan } \\
\text { 2. } & \text { Lab komputer } \\
\text { 3. } & \text { Lab IPA } \\
\text { 4. } & \text { Ruang UKS } \\
\text { 5. } & \text { Sarana } \\
& \text { Olahraga }\end{array}$ & $\begin{array}{ll}\text { 1. } & \text { SMA SANTO } \\
\text { YOSEF } \\
\text { 2. } \\
\text { SMA THB } \\
\text { 3. SMA } \\
\text { SWADAYA }\end{array}$ \\
\hline Lokasi & $\begin{array}{l}\text { 1. } \text { Berada di } \\
\text { Jalan Raya } \\
\text { 2. Dilewati } \\
\text { Angkutan Kota }\end{array}$ & \\
\hline Prestasi & $\begin{array}{l}\text { 1. Juara Lomba } \\
\text { Pidata } \\
\text { 2. Juara Lomba } \\
\text { Pawai Indah } \\
\text { 3. Juara Lomba } \\
\text { volley } \\
\text { 4. Juara Lomba } \\
\text { Futsal }\end{array}$ & \\
\hline $\begin{array}{l}\text { Tenaga } \\
\text { Pengajar }\end{array}$ & $\begin{array}{ll}\text { 1. } & \mathrm{D} 3 \\
\text { 2. } & \mathrm{S} 1\end{array}$ & \\
\hline $\begin{array}{l}\text { Ekstraku } \\
\text { likuler }\end{array}$ & $\begin{array}{ll}\text { 1. } & \text { PMR } \\
\text { 2. } & \text { Paduan Suara } \\
\text { 3. } & \text { Futsal } \\
\text { 4. } & \text { Bola Volly } \\
\end{array}$ & \\
\hline
\end{tabular}

Penyelesaian metode pengambilan keputusan dengan menggunakan AHP dapat dilakukan perhitungan pengolahan data dengan software expert choice 2000. Adapun diagram hierarki pemilihan SMA swasta terfavorit di kota Pangkalpinang adalah sebagai berikut: 

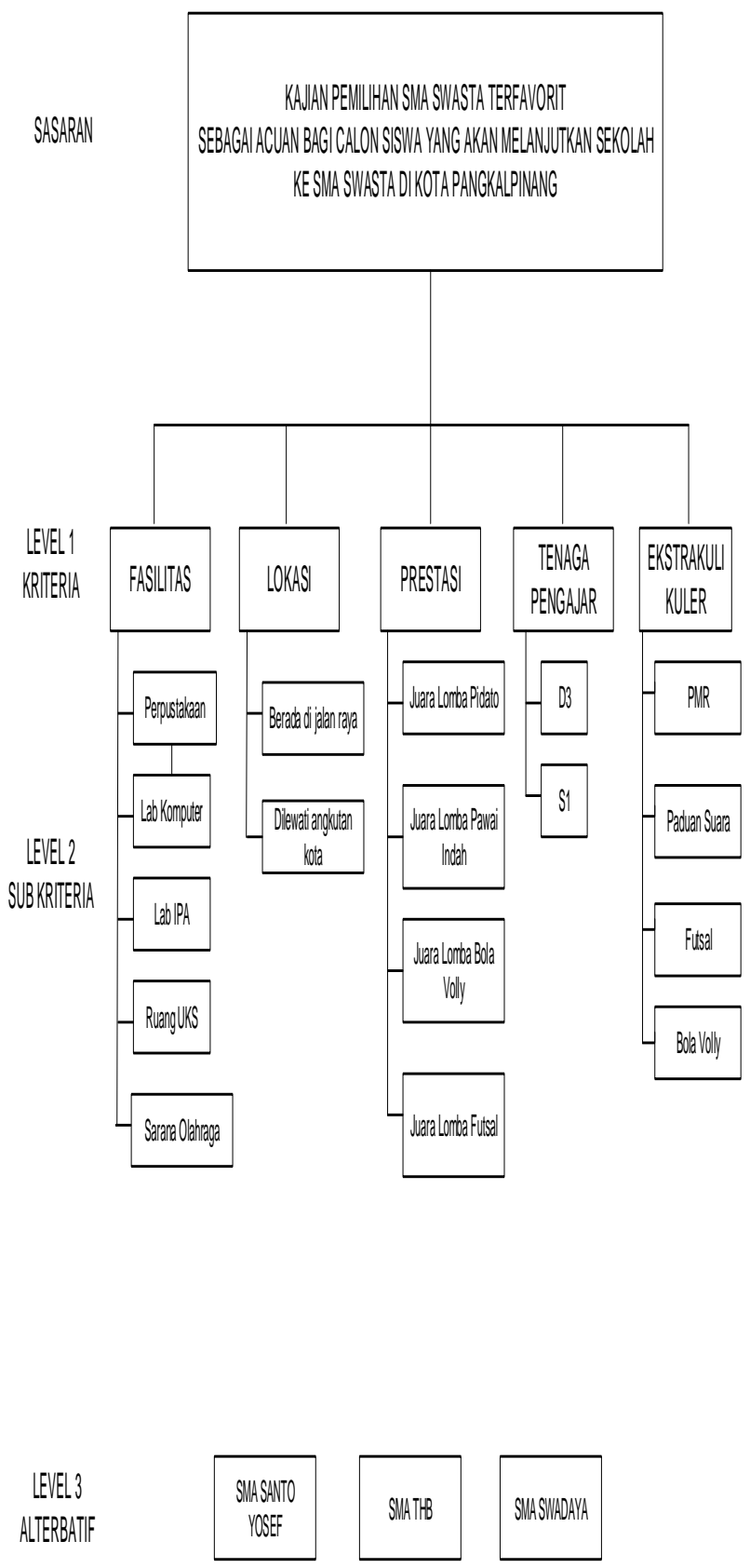

Gambar 2. Diagram Hierarki

\section{HASIL DAN PEMBAHASAN}

Berikut ini merupakan hasil pengolahan data empat orang pakar dari Dinas Pendidikan kota Pangkalpinang untuk goal Kajian Pemilihan Sma Swasta Terfavorit Sebagai Acuan Bagi Calon Siswa Yang Akan Melanjutkan Sekolah Ke Sma Swasta Di Kota Pangkalpinang menggunakan software expert choice 2000 :
Pinitio ith resectts:

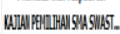

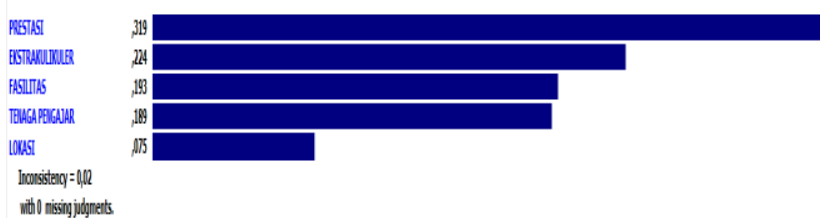

Gambar 3. Bobot Kriteria Level 1

Pada gambar 3, terlihat bahwa kriteria level satu yang paling tinggi bobotnya adalah Prestasi dengan persentase mencapai $31,9 \%$. Kriteria terpenting berikutnya adalah Ekstrakulikuler dengan bobot 22,4\%, kemudian dilanjutkan dengan fasilitas dengan bobot 19,3\%, selanjutnya yaitu Tenaga Pengajar dengan bobot $18,9 \%$ dan kriteria dengan bobot yang terkecil yaitu Lokasi dengan bobot 7,5\%

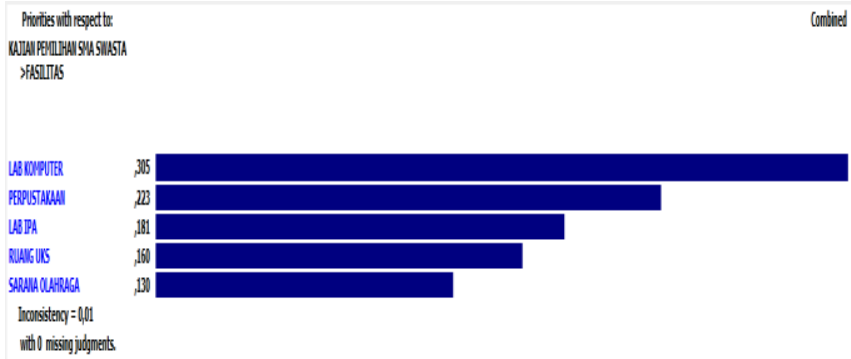

Gambar 4. Bobot Sub Kriteria dari kriteria Fasilitas

Pada gambar 4, terlihat bahwa sub kriteria dari kriteria Fasilitas yang paling besar bobotnya adalah Lab Komputer dengan persentase bobot sebanyak $30,5 \%$, sub kriteria yang menempati posisi kedua yaitu perpustakaan dengan bobot sebesar 22,3\%, kemudian Lab IPA dengan bobot sebesar $18,1 \%$, dilanjutkan dengan sub kriteria Ruang UKS dengan bobot sebesar $16 \%$ dan sub kriteria yang terakhit yaitu Sarana Olahraga dengan bobot sebesar $13 \%$.

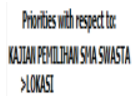

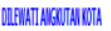

BEAOADIHAN RAYA

Incosisteny:1900

itito nisingijognets

Gambar 5. Bobot Sub Kriteria dari kriteria Lokasi

Pada gambar 5, terlihat bahwa sub kriteria dari kriteria Lokasi yang paling besar bobotnya adalah Dilewati Angkutan Kota dengan persentase bobot sebanyak 69,7\%, dan sub kriteria yang terkecil yaitu Berada di jalan raya dengan bobot sebesar $30,3 \%$. 


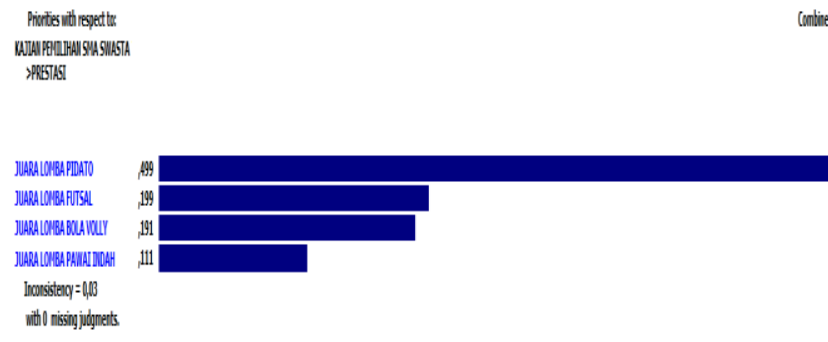

Gambar 6. Bobot Sub Kriteria dari kriteria Prestasi

Pada gambar 6, terlihat bahwa sub kriteria dari kriteria Prestasi yang paling besar bobotnya adalah Juara Lomba Pidato dengan persentase bobot sebesar $49,9 \%$, sub kriteria yang menempati posisi kedua yaitu Juara Lomba Futsal dengan bobot sebesar 19,9\%, kemudian Juara Lomba Volly dengan bobot sebesar $19,1 \%$, dan sub kriteria yang terakhir yaitu Juara Lomba Pawai Indah dengan bobot sebesar $11,1 \%$.

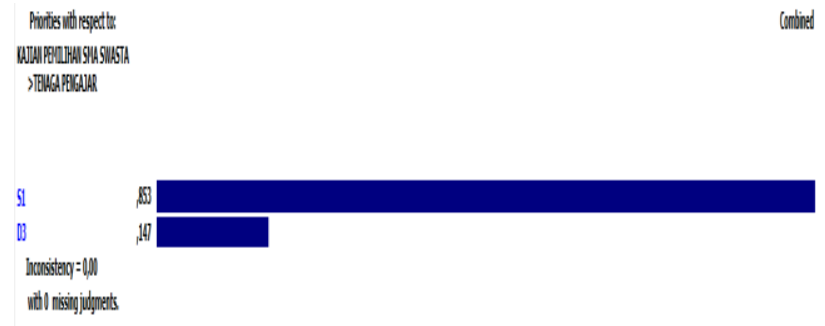

Gambar 7. Bobot Sub Kriteria dari kriteria Tenaga Pengajar

Pada gambar 7, terlihat bahwa sub kriteria dari kriteria Tenaga Pengajar yang paling besar bobotnya adalah S1 dengan persentase bobot sebesar $85,3 \%$, dan sub kriteria yang terkecil yaitu D3 dengan bobot sebesar 14,7\%.

$$
\begin{aligned}
& \text { Piontes ith resectlur }
\end{aligned}
$$

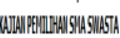

$$
\begin{aligned}
& \text { YGTANALNER }
\end{aligned}
$$

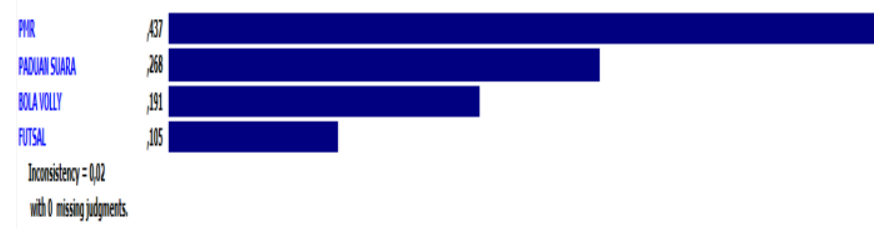

Gambar 7. Bobot Sub Kriteria dari kriteria Ekstrakulikuler

Pada gambar 8, terlihat bahwa sub kriteria dari kriteria Ekstrakulikuler yang paling besar bobotnya adalah PMR dengan persentase bobot sebesar $43,7 \%$, dan sub kriteria yang terkecil yaitu Futsal dengan bobot sebesar 10,5\%.

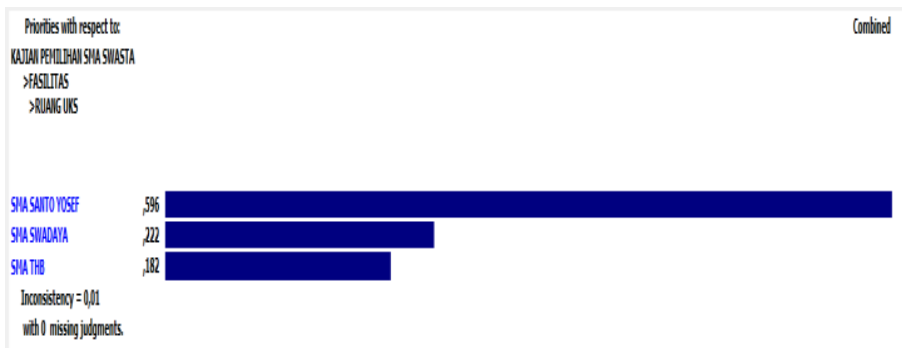

Gambar 8. Bobot elemen alternatif dari subkriteria ruang UKS pada kriteria Fasilitas

Pada gambar 8, terlihat bahwa untuk sub kriteria ruang UKS, SMA Santo Yosef merupakan alternatif yang paling besar bobot nya yaitu 59,6\%, dilanjutkan dengan SMA THB dengan bobot sebesar $22,2 \%$, dan alternatif yang terkecil yaitu SMA Swadaya dengan bobot sebesar 18,2\%.

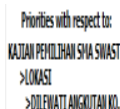

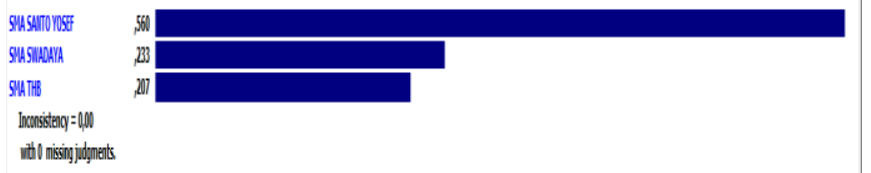

vido mising jobnets

Gambar 9. Bobot Elemen Alternatif sub kriteria dilewati angkutan kota pada kriteria lokasi

Pada gambar 9, terlihat bahwa untuk sub kriteria Dilewati angkutan kota, SMA Santo Yosef merupakan alternatif yang paling besar bobot nya yaitu 56\%, dilanjutkan dengan SMA THB dengan bobot sebesar 23,3\%, dan alternatif yang terkecil yaitu SMA Swadaya dengan bobot sebesar $20,7 \%$.

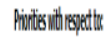

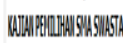 \\ WGEII

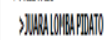

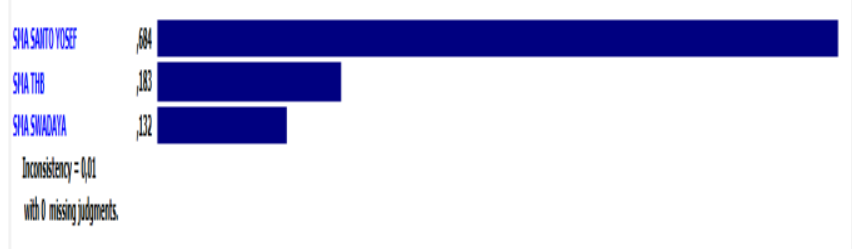

Gambar 10. Bobot elemen alternatif sub kriteria juara lomba pidato pada kriteria prestasi

Pada gambar 13, terlihat bahwa untuk sub kriteria Juara Lomba Pidato, SMA Santo Yosef merupakan alternatif yang paling besar bobot nya yaitu 68,4\%, dilanjutkan dengan SMA THB dengan bobot sebesar 18,3\%, 
dan alternatif yang terkecil yaitu SMA Swadaya dengan bobot sebesar $13,2 \%$.
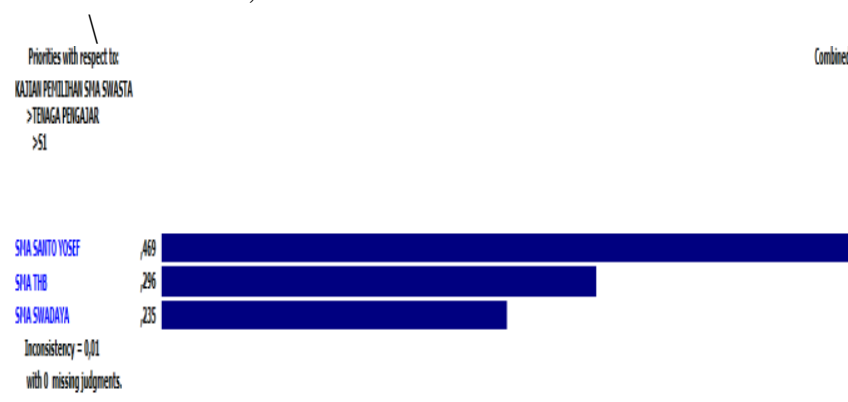

Gambar 11. Bobot elemen alternatif untuk sub kriteria S1 pada kriteria tenaga pengajar

Pada gambar 18, terlihat bahwa untuk sub kriteria Dilewati angkutan kota, SMA Santo Yosef merupakan alternatif yang paling besar bobot nya yaitu $46,9 \%$, dilanjutkan dengan SMA THB dengan bobot sebesar 29,6\%, dan alternatif yang terkecil yaitu SMA Swadaya dengan bobot sebesar $23,5 \%$.

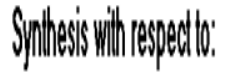

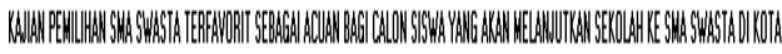 nulum}

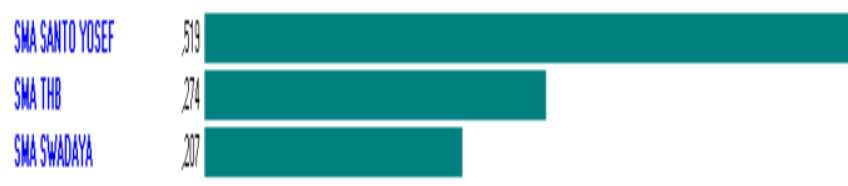

Gambar 12. Synthesis With Respect To Goal

Pada gambar 12, terlihat bahwa alternatif yang terpilih adalah SMA Santo Yosef dengan bobot mencapai 51,9\%. Alternatif terbaik kedua adalah SMA THB dengan bobot $27,4 \%$, dan alternatif yang terakhir adalah SMA Swadaya dengan bobot $20,7 \%$.

\section{PENUTUP}

\section{A. Kesimpulan}

Berdasarkan hasil pengolahan data terhadap pemilihan SMA swasta Terfavorit sebagai acuan bagi calon siswa yang akan melanjutkan sekolah ke SMA swasta di kota Pangkalpinang, maka dapat disimpukan sebagai berikut:

- SMA swasta terbaik yaitu SMA Santo Yosef dengan Bobot 51,9\%. Kemudian dilanjutkan dengan SMA THB dengan bobot 27,4\%.A Alternatif terakhir yaitu SMA Swadaya dengan bobot $20,7 \%$.
- Expert choice 2000 merupakan software yang cocok untuk mengolah data pengambilan keputusan dengan metode AHP.

\section{B. Saran}

Berdasarkan kesimpulan dari penelitian ini, maka peneliti memberikan beberapa saran antara lain:

- Untuk penelitian lebih lanjut diharapkan dapat mengembangkan aplikasi untuk menentukan SMA Swasta Terfavorit di Pangkalpinang.

- Metode AHP diharapkan dapat diimplementasikan dengan menambah metode lain sehingga mendapatkan hasil yang lebih akurat

\section{DAFTAR PUSTAKA}

[1] Faisal, 2015. Sistem Penunjang Keputusan Pemilihan Sekolah Menengah Kejuruan Teknik Komputer Dan Jaringan Yang Terfavorit Dengan Menggunakan Multi-Criteria Decision Making. Jurnal Teknologi Informasi dan Ilmu Komputer (JTIIK) April 2015.

[2] FAISAL, 2015. Sistem Penunjang Keputusan Pemilihan Perangkat Pemrosesan Data Menggunakan Metode Analytical Hierarchy Process (AHP) Dan Multi-Criteria Decision Making (MCDM). Seminar Nasional|Prosiding Konferensi Nasional Sistem Informasi (KNSI 2015), ISSN: 1907-9613 Universitas Klabat Menado Sulawesi Utara 26-28 Februari 2015.

[3] FAISAL, 2015. Sistem Penunjang Keputusan Pemilihan Perangkat Lunak Pengolah Citra Dengan Metode Multi-Criteria Decision Making (MCDM) dan Analytical Hierarchy Process (AHP). Seminar Nasional|Prosiding Seminar Nasional Teknologi Informasi dan Multimedia (SEMNASTEKNOMEDIA 2015), ISSN: 2302-3805 STMIK AMIKOM Yogyakarta 6-8 Februari 2015.

[4] Kusrini. 2007. Konsep dan Aplikasi Sistem Pendukung Keputusan. Yogyakarta. Penerbit Andi.

[5] Marimin. 2004. Teknik dan Aplikasi Pengambilan Keputusan Kriteria Majemuk. Penerbit PT Grasindo, Jakarta.

[6] Roger, R. Flynn, \& Marek, J. Druzdzel. (2007). Decision Support Systems Encyclopedia of Library and Information Science, Second Edition (pp.794-802): Taylor \& Francis, Decision Systems Laboratory School of Information Sciences and Intelligent Systems Program University of Pittsburgh, Pittsburgh, PA 1526. 